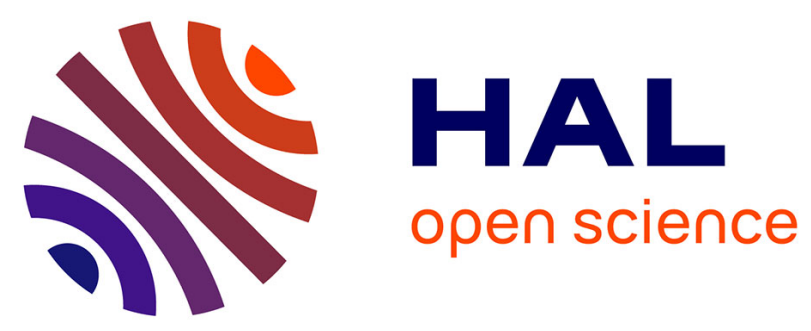

\title{
Adapting the LCA framework to environmental assessment in land planning
}

\author{
Eléonore Loiseau, P. Roux, G. Junqua, Pierre Maurel, Véronique Bellon
}

Maurel

\section{- To cite this version:}

Eléonore Loiseau, P. Roux, G. Junqua, Pierre Maurel, Véronique Bellon Maurel. Adapting the LCA framework to environmental assessment in land planning. International Journal of Life Cycle Assessment, 2013, 18 (8), pp.1533-1548. 10.1007/s11367-013-0588-y . hal-02598541

\section{HAL Id: hal-02598541 \\ https://hal.inrae.fr/hal-02598541}

Submitted on 15 May 2020

HAL is a multi-disciplinary open access archive for the deposit and dissemination of scientific research documents, whether they are published or not. The documents may come from teaching and research institutions in France or abroad, or from public or private research centers.
L'archive ouverte pluridisciplinaire HAL, est destinée au dépôt et à la diffusion de documents scientifiques de niveau recherche, publiés ou non, émanant des établissements d'enseignement et de recherche français ou étrangers, des laboratoires publics ou privés. 


\title{
Adapting the LCA framework to environmental assessment in land planning
}

\author{
Eléonore Loiseau • Philippe Roux • Guillaume Junqua • \\ Pierre Maurel • Véronique Bellon-Maurel
}

\begin{abstract}
Purpose Since the implementation of the European directive $(E C / 2001 / 42)$ on strategic environmental assessment, an ex ante evaluation has become mandatory for plans and programs. This requirement could have significant consequences for the environment. Local authorities, who are in charge of land planning issues, must therefore conduct such assessments. However, they are faced with lack of uniform methodology. The aim of this paper is thus to propose a methodological framework for the required environmental assessment stages in land planning.

Methods Life cycle assessment (LCA) has been identified as a promising tool to perform environmental assessment at a meso-level (i.e., territories). Yet, the standardized LCA framework has never been used for assessing the environmental impacts of a territory as such, which can be explained by the complexity that its application would
\end{abstract}

\section{E. Loiseau}

AgroParisTech ENGREF, 19 avenue du Maine,

75732 Paris cedex 15, France

E. Loiseau $(\bowtie) \cdot P$. Roux $\cdot$ V. Bellon-Maurel

Irstea, UMR ITAP, ELSA (Environmental Lifecycle and

Sustainability Assessment), 361 rue Jean-François Breton,

BP5095, 34196 Montpellier cedex 5, France

e-mail: eleonore.loiseau@irstea.fr

G. Junqua

Ecole des Mines d'Alès, LGEI, ELSA (Environmental Lifecycle and Sustainability Assessment), 6 avenue de Clavières,

30319 Alès, France

P. Maurel

Irstea, UMR TETIS, 361 rue Jean-François Breton, BP5095,

34196 Montpellier cedex 5, France involve. Four major methodological bottlenecks have been identified in this paper, i.e., (1) functional unit definition, (2) boundary selection, (3) data collecting, and (4) the refinement of the life cycle impact assessment phase in order to provide useful indicators for land planning. For each of these challenges, recommendations have been made to adapt the analytical framework of LCA.

Results and discussion A revised framework is proposed to perform LCA of a territory. One of the major adaptations needed concerns the goal and scope definition phase. Henceforth, the association of a territory and the studied land planning scenario, defined by its geographical boundaries and its interactions with other territories, will be designated as the reference flow in LCA. Consequently, two kinds of indicators will be determined using this approach, i.e., (1) a vector of environmental impacts generated (conventional LCA) and (2) a vector of land use functions provided by the territory for different stakeholders (e.g., provision of work, recreation, culture, etc.). This revised framework has been applied to a theoretical case study in order to highlight its utility in land planning.

Conclusions This work is a first step in the adaptation of the LCA framework to environmental assessment in land planning. We believe that this revised framework has the potential to provide relevant information in decision-making processes. Nonetheless, further work is still needed to broaden and deepen this approach (i.e., normalization of impacts and functions, coupled application with GIS, uncertainties, etc.).

Keywords Environmental impacts · Land planning · Land use functions $\cdot$ Life cycle assessment $\cdot$ Territory

\section{Introduction}

As stated during the Rio Summit in 1992, the involvement of local authorities is essential for meeting the challenges of 
sustainable development, and this is particularly true for the management of resources and for the mitigation of human activities impacts on the environment (United Nations 1992). Local authorities are notably responsible for strategic issues like developing plans and programs related to spatial planning. During this decision-making process, main guidelines on human activity distribution and organization are set (Chanard et al. 2011). As the implementation of these plans and programs can have significant environmental impacts, they may be subject to an ex-ante environmental assessment as required in the European Union following the implementation of the European directive (2001) on strategic environmental assessment. However, the European Commission (2009) reported that the Member States, when implementing environmental assessment, are faced with incoherency concerning content definition, scope, and baseline analysis.

Different analytical tools can be used to perform such assessments (e.g., Material Flow Analysis, the Ecological Footprint, emergy). Among them, life cycle assessment (LCA) has been identified as a promising tool as it can be used to perform a comprehensive assessment of a territory as a whole (Loiseau et al. 2012). Indeed, LCA has been developed to assess the environmental impacts and resources used throughout a product's life cycle, i.e., from raw material acquisition to waste management, via production and use phases (ISO 2006a). Its ability to avoid problem-shifting between life cycle stages, territories, and environmental impacts is a significant asset (Finnveden et al. 2009). Few studies perform LCA at a territory scale to assess the impacts of specific human activities. Siqueira Lemos (2011) or Goldstein (2012) assessed the impacts of consumption activities on a Portuguese territory or on big cities (Beijing, London, and Toronto) respectively. Similarly, an approach based on LCA has been developed to provide macro-level life cycle indicators so as to monitor the consumption of the EU-27 and Germany (European Commission 2012a). Azapagic et al. (2007) and Yi et al. (2007) studied activities in a city or in a regional context (e.g., transportation or industrial activities). Finally, LCA has been applied to evaluate different energy resources management scenarios as in Sweden municipalities (Björklund 2012) or for water systems like in Sydney (Lundie et al. 2004). Nevertheless, the standardized LCA framework has never been applied as such to study a territorial system (Loiseau et al. 2012). The presence of methodological bottlenecks (e.g., functional unit definition) can partly explain the reluctance to apply LCA in such contexts.

Consequently, one of the aims of this paper is to review the methodological issues involved in the application of LCA for the environmental assessment of a territory. As defined by Moine (2006), a territory can be described as a complex, dynamic, and open system, which associates a geographical space on the one hand, and a local society made up of decision makers, stakeholders, and citizens who manage, use, and develop it on the other. The system studied will be defined by the association of a geographical space and an administrative organization in charge of land planning questions. The scale of the system is a function of local territory dimensions. In France, this corresponds to a community of municipalities, which cooperate through a joint development project. The total area of this community can range from 100 to $1,000 \mathrm{~km}^{2}$.

The main purpose of our work was to adapt the LCA framework to environmental assessment dedicated to land planning. We propose a methodology designed to provide relevant information on environmental issues involved in decision-making processes using (1) a global approach which encompasses the cumulative effects of the overall activities occurring on a territory; (2) the identification of environmental burden shifting from one impact category to another, but also from the territory to other territories, in relation to the land use functions provided by the land use planning scenario; and (3) the determination of the most harmful territorial activities for local environmental and which may require a complementary environmental risk assessment.

Finally, the revised framework is applied on a theoretical case study to highlight its utility for local authorities addressing land planning issues.

\section{Methodological proposals}

The aim of an LCA on territorial systems is to provide relevant information about the potential environmental impacts of scenarios for the decision-making process involved in land planning. Nonetheless, the application of life cycle assessment to land planning raises specific methodological issues. Guinée et al. (2011) pointed out the need for further research in this area in order to define and propose appropriate models and methods. Our approach has been to list the specific characteristics of a territory and to analyze to which extent they were compliant with LCA or, on the contrary, generate methodological issues. A territory is a multifunctional, open, dynamic, and complex system as well as a system embedded in a local context (geographic and societal) (Moine 2006; Wiggering et al. 2003). The multifunctionality involved can make the functional unit definition step problematic. The terms "open" and "dynamic" raise questions about the boundary selection. Moreover, the complexity of the system can make the data collection difficult to compile. Finally, local context has to be taken into account when providing indicators for decisionmaking. These four bottlenecks are classified according to the four methodological phases defined by ISO standards (ISO 2006a, b) (Fig. 1). 
Fig. 1 Identification of the major bottlenecks $(B N)$ linked to the LCA of territories in each of the four LCA phases

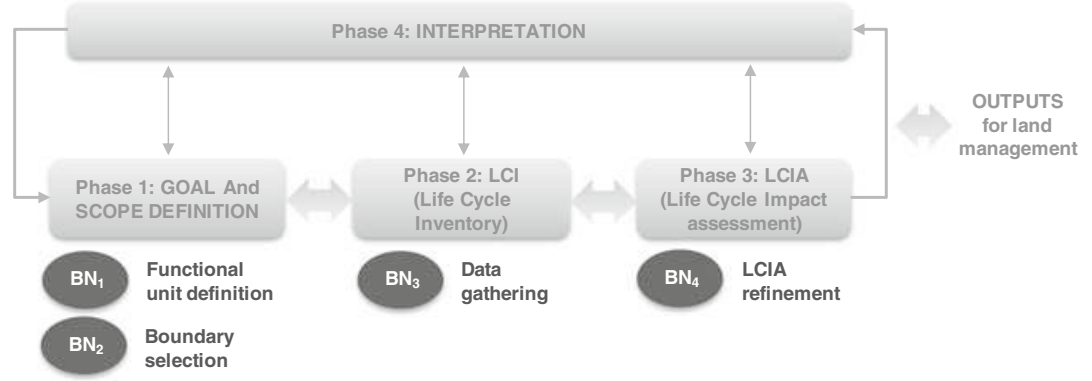

We were able to identify four main bottlenecks. All of which will be discussed hereafter and proposals will be made to adapt the LCA framework to make it more relevant for the environmental assessment of territories in decisionmaking process.

\subsection{Functional unit and reference flow}

\subsubsection{A revised approach}

A functional unit is a "quantified performance of a product system for use as a reference unit" (ISO 2006a). Its purpose is "to provide a reference to which the inputs and outputs are normalized (in a mathematical sense)". Its definition is therefore crucial for further analysis as it ensures that alternatives are comparable on a common basis (Cooper 2003). However, it can be a source of potential errors when handling, for example, different kind of functions (Reap et al. 2008). According to ISO (1998), the functional unit definition phase can be divided into four stages (e.g., see the example for a watch in Fig. 2). The last stage consists in determining the reference flow which specifies the amount of product necessary per functional unit under assessment (ISO 2006a).

In the case of territorial assessment, the studied system is by definition multifunctional. It is hence necessary to adapt the LCA framework to account for this specificity. This issue of multifunctionality is quite similar to the one encountered in agriculture for farm level assessments. Haas et al. (2000) proposed to define several functional units including the farm itself. Baumgartner et al. (2011) went further by defining and assessing simultaneously a set of functional units at the farm level (e.g., a land management function, a financial function, and a production function). In the case of a territory, whatever the land planning scenario, the subject of the study will be the territory defined by its geographical boundaries. The territory with a specific land planning scenario is thus called the reference flow. Despite this modification, we still need to determine and to assess the different functions provided by the territory for each studied land planning scenario. This is a crucial measure as it provides relevant information for the interpretation step. It is essential for decision-making to be able to assess the environmental impacts of scenarios regarding their performances (e.g., the number of citizens housed, the annual agricultural production, the number of tourist overnights, and so on). Consequently, in our revised approach, we propose to replace the functional unit definition by the identification and selection of appropriate functions related to a pre-determined reference flow (Fig. 3).

The use of a pre-determined flow is close to the approach recommended by the ILCD handbook (European Commission 2010) for a multifunctional product. Yet, the difference stems from the fact that the product has been designed on purpose to fulfill a number of functions, whereas the land use functions are a result of the implementation of a land planning scenario and need to be quantified as the environmental impacts.

\subsubsection{Identification of land use functions}

A territory can be defined as a multifunctional system. Originally, the concept of multifunctionality was coined and discussed from an agricultural perspective by three
Fig. 2 Functional unit definition and its related reference flow (adaptation of the ISO 1998 framework with an example of a watch)

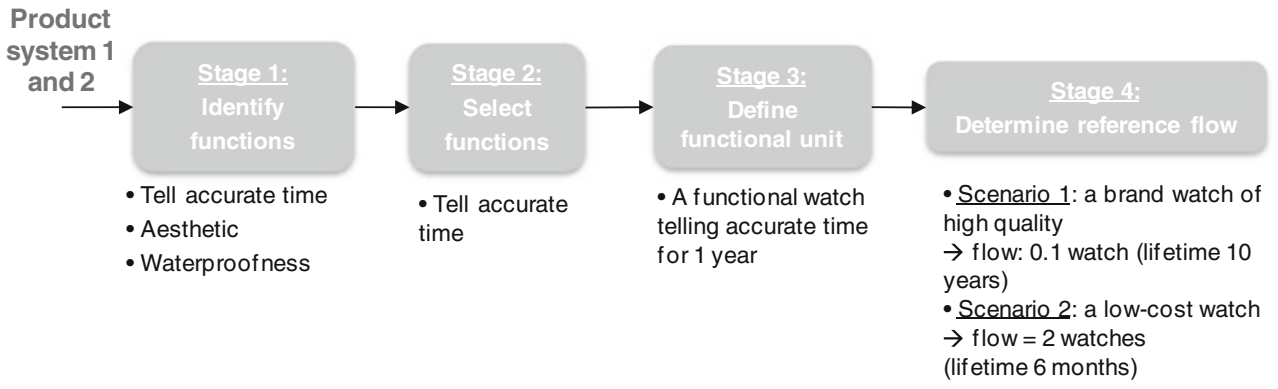


Fig. 3 A revised approach which replaces the functional unit definition phase

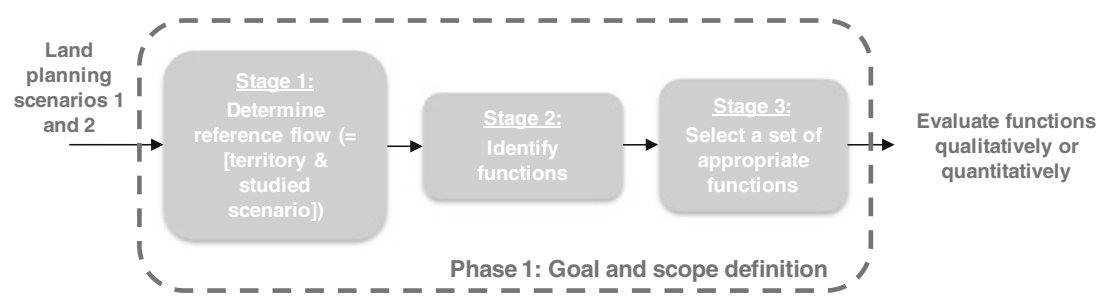

major organizations: the FAO (the Food and Agriculture Organization), the OECD (the Organization for Economic Co-operation and Development), and the European Union (Wiggering et al. 2003). It was an economic concept that provided the different outputs produced by the agricultural sector (i.e., commodities but also other externalities like environmental and social services) (Helming et al. 2011a). Later on, attempts were made to adapt this concept to the process of sustainable land development. One of the first steps involves the definition of the various environmental, social, and economic functions of land use (Wiggering et al. 2003). Figure 4 illustrates the potential functions, which may be aggregated to a certain degree, that have been attributed to a territory in the literature. Some of these functions are mainly environmental. As such, they include provision of resources and a set of ecosystem services as defined by Costanza et al. (1997). Their assessment may provoke a double-counting issue as impacts on resources and ecosystem services due to human activities can also be quantified in LCIA. However, little attention has been paid to biotic resources in LCIA (Finnveden et al. 2009) and, to date, no life cycle impact assessment method includes impacts on ecosystem services as a whole (although the new LCIA methodology, Impact World $+^{1}$, should address this by using economic valuation to aggregate midpoint indicators into a single area of protection representing ecosystem services loss; Cao et al. 2012). Therefore, when no characterization factors are available for ecosystem services, we recommend assessing them as a part of environmental functions. From a territorial perspective, it may be more valuable to differentiate the environmental impacts incurred by human activities from the environmental functions fulfilled by a territory and used to meet human needs.

Among the propositions of potential land use functions, the land use function (LUF) framework defined by Pérez-Soba et al. (2008) in the SENSOR project (Sustainability impact assessment: Tools for Environmental, Social and Economic Effects of Multifunctional Land Use in European Regions) and further developed by Paracchini et al. (2011) has been taken up in other land planning studies (Banski et al. 2011; Helming et al. 2011a, b; Reidsma et al. 2011). LUFs can be defined by private and public goods and services produced by

\footnotetext{
${ }^{1}$ http://www.impactworldplus.org/en/methodology.php
}

the multiple land uses at a territorial level. We have adopted this framework to propose a set of land use functions (and corresponding goods and services) (Table 1). In addition, to illustrate how these land use functions may be analyzed, we have selected a set of indicators commonly used by stakeholders when studying their territory, based on a work previously conducted in the European project SENSOR. However, the choice of indicators and their links to land use functions requires further work.

To enhance the assessment of the land use functions, additional data may be added such as the stocks of resources or the total wastewater treatment capacities. Such information will provide a sort of territory scorecard.

\subsubsection{Selection and evaluation of land use functions}

The above list of functions and related indicators (see Table 1) is not exhaustive and can be adapted to each study. Other indicators could also be defined and assessed such as landscape value or well being indicators. Stakeholders are the ones able to choose the relevant functions in relation to their values when defining the objectives of the study. Moreover, it may be beneficial to involve, from the very beginning, stakeholders throughout the environmental assessment process. Their involvement can lead to more comprehensive assessments and can favor consensus among them (Thabrew et al. 2009).

The evaluation of the selected functions is an integrant part of the adapted framework we propose. Some of these indicators can be directly quantified from the description of the activities located on the territory (e.g., number of inhabitants). For others, additional data are required to quantify them (e.g., provision of work). Lastly, some indicators are not quantified, and only a qualitative assessment could be carried out based on expert judgments or stakeholder perceptions (e.g., well being).

To further improve the assessment, a sort of normalization step could be performed. As for environmental impacts, indicators on land use functions could also be normalized. It would permit to highlight the specificities of the territory under study (e.g., low provision of works, high provision of dwellings, etc.) by comparison with another territorial reference. As local territories are embedded within different systems, several references, such as a region or a nation, could be chosen. 
Fig. 4 The multifunctionality of territories: literature review of potential functions. [1] Datar 2003, [2] Pérez-Soba et al. 2008, [3] García et al. 2009, [4] Jean 2009, [5] Gómez-Limón et al. 2012

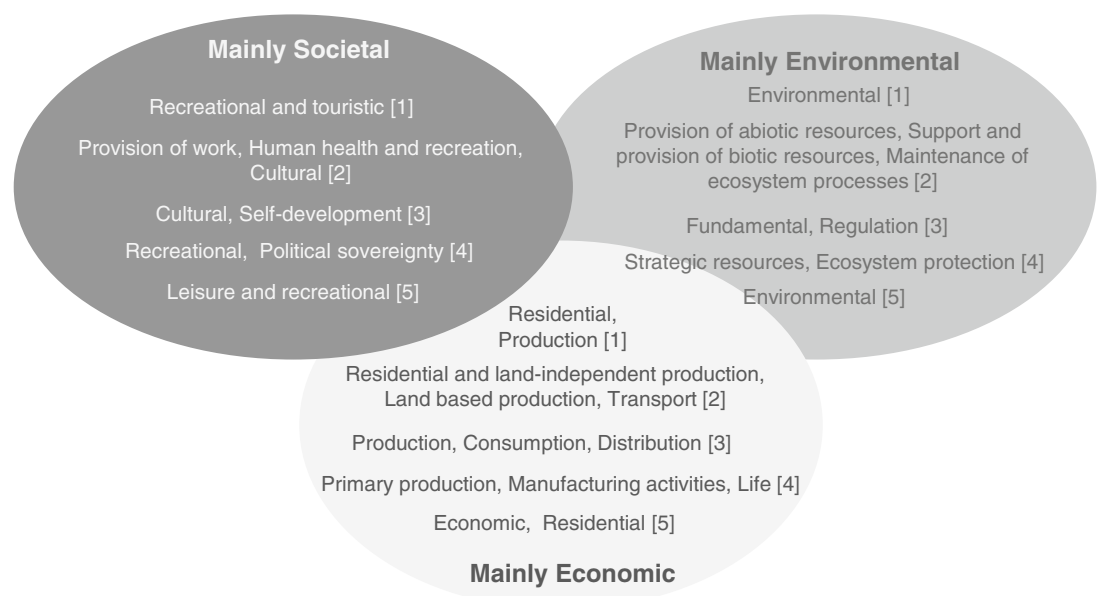

\subsection{Boundary selection}

With regard to the reference flow in a conventional LCA, "the system boundary determines which unit process shall be included within the LCA" (ISO 2006a). Concerning territorial assessment, the issue at stake is how to allocate responsibility of environmental impacts to various territorial scales (local, regional, and global). It is particularly relevant for developed countries which tend to transfer their environmental loads to developing countries (Muradian et al. 2002). Consequently, different principles of responsibility can be established (Eder and Narodoslawsky 1999): a territory can be responsible for impacts caused by its final consumption, by its production, or by both. The consumption-based approach includes all goods and services required for the residential consumption of a defined territory. On the other hand, the production-based approach focuses on goods and services produced by production activities located in a defined territory (Ferng 2003).

Eder and Narodoslawsky (1999) put forward that the concept of total responsibility (including consumption and production), which they maintain should be implemented even if it generates a double counting at a global scale. In our approach, we have decided to implement this principle of responsibility for boundary selection by including all unit processes related to domestic production as well as final domestic consumption in our assessment. However, other principles of responsibility can also be adopted.

\subsection{Data collecting}

Owing to the boundary choice, system modeling should include consumption activities of residents (permanent residents, i.e., inhabitants; and temporary residents, i.e., tourists) and production activities. As proposed by Kaenzig and Jolliet (2006), consumption activities can be partitioned into five groups: (1) housing, (2) transport, (3) food, (4) goods, and (5) services. Moreover, as end-of-life activities are an important issue at a local scale, we suggest assessing them separately regardless of whether they are located or not on the territory. Production activities are dealt with using the European Union official classification of economic activities, called NACE (Rev. 2) (Eurostat 2008) (see Electronic supplementary material 1, S.1).

Two main steps have been identified for modeling human activities from a life cycle perspective. The first, i.e., the

Table 1 Example of a set of land use functions and their related goods and services adapted from Pérez-Soba et al. (2008) and Banski et al. (2011) and proposals for associated indicators of evaluation

\begin{tabular}{|c|c|c|}
\hline Functions & Examples of goods and services & Some examples of indicators of performance \\
\hline Provision of work & Employment provision, job security, job quality & Employment rate $(\%)$, number of jobs \\
\hline Human health, recreation and culture & $\begin{array}{l}\text { Access to health services, access to recreational } \\
\text { services, landscape aesthetics and quality }\end{array}$ & Number of tourists \\
\hline Land-based production & Provision of food, wood, renewable energy & Area harvested \\
\hline $\begin{array}{l}\text { Residential, transport, and land } \\
\text { independent production }\end{array}$ & $\begin{array}{l}\text { Industrial and residential settlements, public } \\
\text { transport services }\end{array}$ & $\begin{array}{l}\text { Number of inhabitants, gross domestic } \\
\text { production (GDP, } € \text { ), equipment density }\end{array}$ \\
\hline Provision of abiotic resources & $\begin{array}{l}\text { Regulation of the supply and the quality of air, } \\
\text { minerals, and water }\end{array}$ & Share of dwellings connected to sewage \\
\hline Provision of biotic resources & Preservation of biodiversity & Area protected \\
\hline
\end{tabular}


activity inventory, consists in collecting detailed information on the activities located on the territory. The second step is to connect this information to existing LCA database in order to obtain a life cycle inventory of all activities (Fig. 5).

\subsubsection{Activity inventory}

Local data (e.g., local statistics, land cover maps, and registers of polluting industries) are used to identify the main activities that take place on the territory. Next, detailed descriptors must be developed for each activity (e.g., for a given manufacturing plant, the descriptor of activity will be its annual output). These descriptors will help us to make a connection with existing LCA databases (see Electronic supplementary material 2, S.2, for examples of descriptors).

Two approaches can be adopted to obtain data about activity descriptors. On the one hand, top-down approaches use national data such as national statistics. To obtain data for local scales, a downscaling process is run (Minx et al. 2011). This adjustment is performed using proxy factors which estimate local or regional data on the basis of a scaled ratio (Browne et al. 2011). Their use could induce bias as territories can have their own specificities and could differ from average national characteristics (e.g., an employment rate different from the national average) (Browne et al. 2011). On the other hand, bottom-up approaches are based on local data (i.e., local statistics, surveys, interviews, etc.). Bottom-up approaches provide more accurate estimates, but local data are not always available and can be costly to produce (Browne et al. 2008).

\subsubsection{Connection to LCA database}

Depending on the kind of data collected for the activity descriptors, i.e., physical flows or monetary flows, two kinds of life cycle inventory databases can be used. For physical flows, a LCA based on physical processes will be performed thanks to the direct connection of activity descriptors to existing LCA databases such as Ecoinvent (Swiss Centre for Life Cycle Inventories $^{2}$ ). It is seen as a bottom-up approach. On the other hand, for monetary flows, top-down modeling may be carried out through environmental input output tables (EIOT). They can account for the quantities of pollutants emitted and of natural resources consumed for each monetary unit of production for a given sector (Suh and Huppes 2005).

Process LCA can be used to compile detailed data about the process under study and is easy to implement. However, it can be time consuming and certain upstream processes could be missing if cut-off criteria are not properly implemented. On the contrary, EIOT does not require cut-off criteria (Suh and

\footnotetext{
$\overline{{ }^{2} \text { www.ecoinvent.ch }}$
}

Huppes 2005), but the inventory can still be incomplete as some activities (e.g., small and medium-sized enterprises) are poorly represented and the coverage of elementary flows is more limited (Suh et al. 2004). Then, it is frequently assumed that imported products are made through the same technologies as the ones used by the domestic economy (Wiedmann et al. 2007), which can lead to inaccurate estimations (Weidema et al. 2005). Besides, EIOT focus on the production stage and so the use and the end-of-life stages are not included (Suh and Huppes 2005). Finally, errors may occur due to allocation uncertainties as the impact of any production output from a sector is understood to be proportional to the product's market price. This assumption ignores product diversity and joint production between industries (Lenzen 2001). In addition, small and medium-sized enterprises are poorly represented.

\subsubsection{The double-counting issue}

The production and consumption approaches we propose here may generate double-counting issues. As highlighted in Lenzen (2008), life cycle inventories of both consumer items (purchases at the end of supply chain) and producer items (intermediate inputs in the supply chain) may be added together when these approaches are used. This can lead to "supply-chain overlap" as the production activities within the territory can be directly or indirectly linked to consumption of its inhabitants (Wilting and Ros 2006). For instance, a part of agricultural production could be locally re-injected for local consumption. If domestic consumption is high in the studied territory, supply-chain overlap may be significant and can lead to undesirable double counting. As data on the percentage of products consumed locally is scarce, we will not take into account potential direct local use of items produced in the territory. This may lead to double counting which is unavoidable in first approximation. In the approach we propose, the results will be provided separately for (1) production and (2) consumption for the same territory. If the aim of the study is to perform an accurate environmental baseline, a better modeling of the intra-territorial flows will be needed to avoid double counting.

\subsection{LCIA refinement}

For better decision-making, it is useful to know which impacts are directly linked to territorial activities and which are indirectly induced by these activities (Wilting and Ros 2006). This involves "foreground" and "background" processes in LCA. Moreover, in the context of land management, the need for spatial differentiation in life cycle impact assessment (LCIA) is crucial as decision makers want to know their local potential impacts (Finnveden and Nilsson 2005). Both concepts are addressed below. 
Fig. 5 Building up the life cycle inventory of human activities on a territory

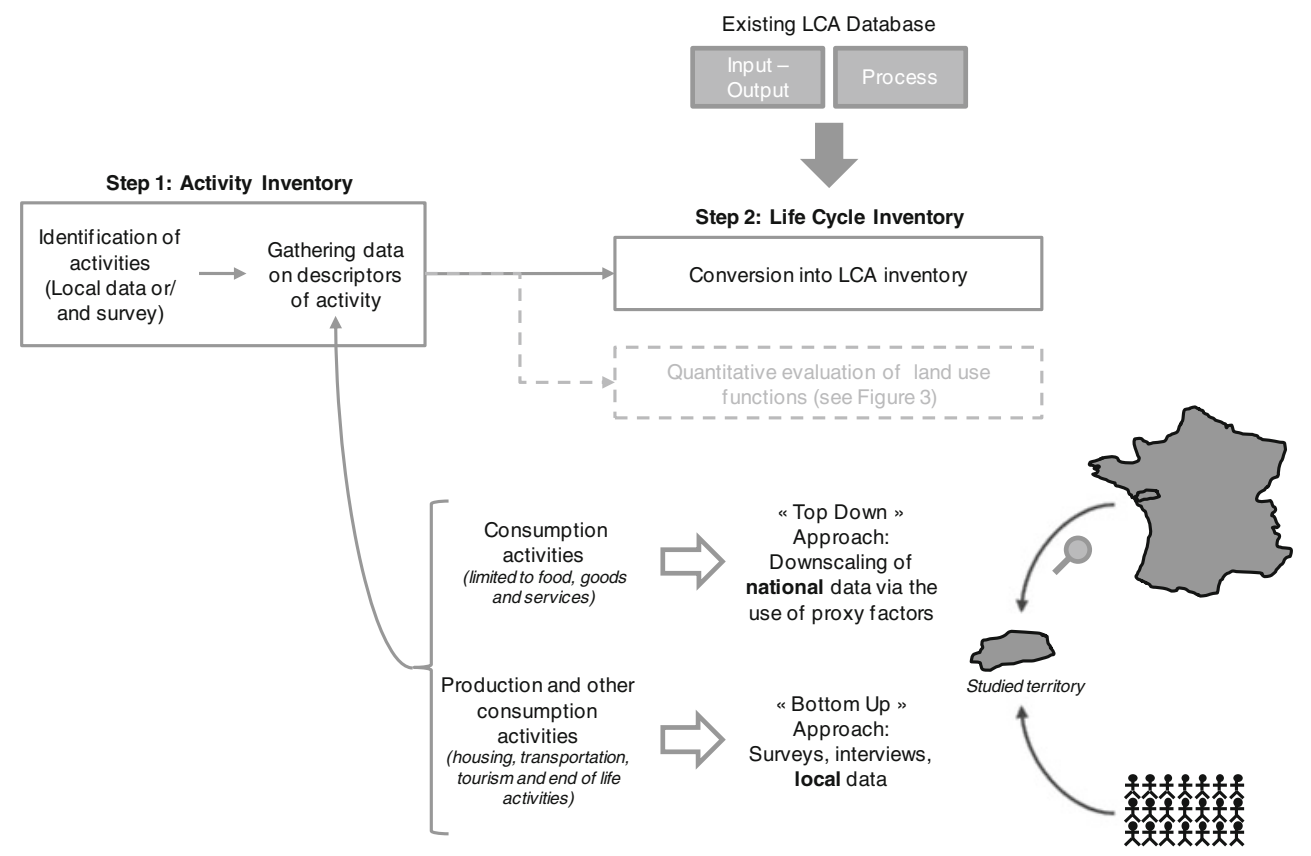

\subsubsection{Territorial foreground and background systems and associated direct and indirect environmental burdens}

The terms "foreground" and "background" systems were used for the first time by Udo de Haes et al. (1994) concerning data quality. They differentiated "foreground data" which are specifically related to the studied product system (such data need to be as real as possible) and "background data" which are required for, but not specifically linked to, the product system (such data may be average values). The "foreground system" refers to processes under the influence of the decision makers that have commissioned the LCA, whereas decision makers have no direct influence on "background" system (Frischknecht 1998). This definition has been adopted in several studies (Tillman 2000; Spielmann et al. 2004; Ekvall et al. 2005).

Azapagic et al. (2007) proposed a definition suited to the study of an urban environment. Here, the "foreground system" refers to a set of activities or processes of direct interest that deliver the defined functional unit (i.e., from activities located on the territory). Meanwhile, the "background system" supports the activities in the foreground system by supplying it with the required goods and services. In this framework, the foreground system includes all pollution sources of primary interest in an urban environment. These pollution sources are responsible for direct burdens whereas indirect burdens occur elsewhere in the life cycle. We propose to adapt these definitions to make a distinction between the set of activities which take place on the territory, hereafter called the "territorial foreground system", and the activities induced by this "territorial foreground system" and which occur elsewhere in the life cycle, hereafter called the "territorial background system". These concepts are summarized in Fig. 6. Ultimately, when assessing results of LCA in land planning, a distinction between direct burdens, or "in-site" burdens (induced by the territorial foreground system), and indirect burdens, or "off-site" burdens, will be made.

For each inventoried activity, proposals to differentiate direct and indirect burdens are provided (see Electronic supplementary material 3, S.3).

\subsubsection{Spatial differentiation}

In LCIA, the inventory data are converted into contributions to environmental impacts (Rebitzer et al. 2004), but as emissions from processes carried out in different sites are combined, the spatial information is lost (Owens 1997).

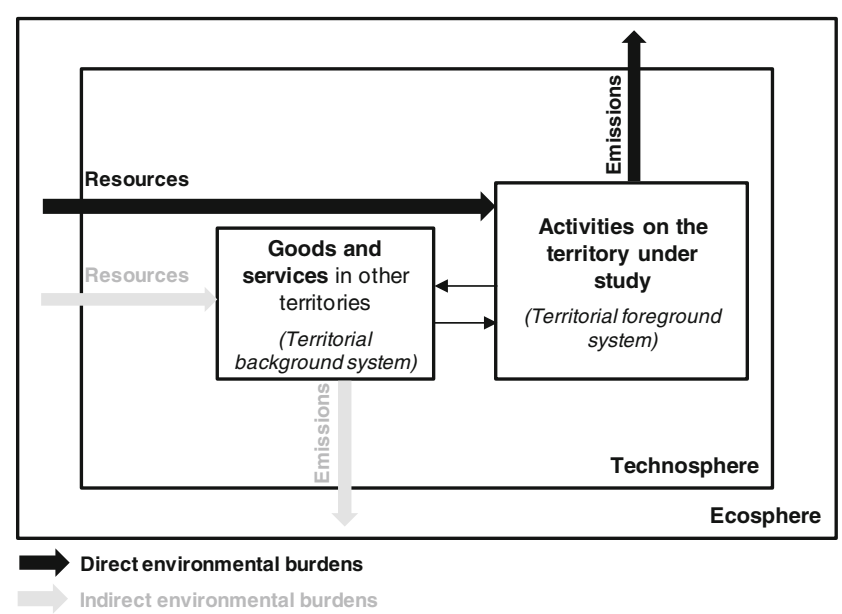

Fig. 6 Definition of the territorial foreground and background subsystems and their related direct and indirect impacts (adapted from Azapagic et al. 2007) 
This leads to poor correlation between the predicted potential environmental impacts and the expected occurrence of actual environmental impacts, except for global impacts such as climate change or ozone depletion (Potting and Hauschild 1997). The inclusion of spatial differentiation in LCA has been widely debated in the 1990s and has been identified as a priority research (Udo de Haes 1996). Initial works were carried out in the early 2000s such as those concerning acidification (Potting et al. 1998), eutrophication (Huijbregts and Seppälä 2000; Huijbregts et al. 2000), or human health (Krewitt et al. 2001). Over the last decade, modeling approaches for spatial differentiation of nonglobal impacts have been widely developed and have been integrated in current LCIA methods such as EDIP2003 (Scandinavia) (Hauschild and Potting 2003), TRACI (USA) (Bare et al. 2003), Impact 2002+ (Europe) (Jolliet et al. 2003), or LUCAS (Canada) (Toffoletto et al. 2006). The new LCIA method, Impact World+, will propose regionalized characterization factors for the entire planet.

Impacts occur at different scales (Owens 1997). Potting and Hauschild (2005) proposed three levels of spatial differentiation, (1) site-generic level which represents global impacts, (2) a site-dependent level which covers regional impacts (tens to hundreds or thousands of square kilometers), (3) and a site-specific level which represents local impacts ( 0 to $10 \mathrm{~km}^{2}$ ). However, in practice the distinction between regional and local is not straightforward. As a result, we will only consider two categories of impacts, i.e., global (climate change, ozone depletion, fossil depletion, and metal depletion) and non-global impacts (photochemical oxidant formation, human toxicity, particulate matter formation, ionizing radiation, eutrophication, acidification, ecotoxicity, and land use) (Owens 1997; Udo de Haes et al. 2002; Bare et al. 2003; Toffoletto et al. 2004; Curran 2006).

\subsubsection{LCIA indicator classification}

In order to propose relevant indicators for the decisionmaking process, we suggest classifying environmental impacts according to the two preceding criteria: (1) direct or indirect impacts, and (2) global or regional/local impacts. For instance, GHG generated by local transportation is a direct/global impact, whereas eutrophication generated in a pork-producing country providing sausages consumed in the territory is an indirect regional impact. It is crucial for a decision maker to know to which extent regional/local direct impacts are generated on the territory under his authority. Identifying the direct local or regional impacts due to territorial activities allows us to highlight activities which need special attention in a local decision-making context. One way to deepen the analysis is to conduct an environmental risk assessment (ERA) of these activities, which better integrate site-specific characteristics, in order to quantify the impacts. Consequently, this screening process can browse all human activities and their related potential impacts before conducting an ERA on a specific activity as it is current practice.

\subsection{Conclusion: main methodological advance}

Applying LCA to land planning is not straightforward as we are operating outside standard process-oriented LCA schemes. Adaptations made to the conventional LCA procedure (see Fig. 1) for "territorial LCA" are shown in Fig. 7.

One of the major modifications we propose concerns the functional unit definition. In "territorial" LCA, the reference flow is defined a priori by the association of a territory and of a studied land planning scenario. Unlike cradle-to-grave LCA, the starting point is therefore the reference flow and no longer the functional unit. The functional unit results from the choice of the reference flow, i.e., the territory and its associated land use scenario. In other words, the services provided (FUs) by two land planning scenarios on a same territory will be different and should be assessed as well as the associated impacts. It means that, unlike with conventional LCA, two outputs are provided by our approach, i.e., not only environmental impacts but also goods and services, which are both related to the human activities located on the territory. These outputs are in the form of two vectors: one vector of potential environmental impacts and one vector of land use functions grouping together the selected goods and services provided by the territory.

Below, we will apply this conceptual framework to a theoretical case study, to highlight its inherent strengths and weaknesses.

\section{Case study}

\subsection{Materials and methods}

\subsubsection{Application to a theoretical case study}

A theoretical territory has been defined as the subject of our case study. It is located on the French Mediterranean coast. It covers an area of $200 \mathrm{~km}^{2}$ and hosts a population of approximately 92,000 inhabitants that is divided into nine municipalities. It is characterized by significant sprawl around the municipal centers (Fig. 8).

There are two major sources of income: tourism (principally based on outdoor accommodation, i.e., campgrounds) and viticulture. The coast is also home to oyster and mussel farming. In addition, there is an industrial zone comprised of specific plants such as a fertilizer production plant and a biodiesel production unit. Two major communication routes (i.e., a highway and a railway track) cut through the territory. 
Article published in International Journal of Life Cycle Assessment, 2013, 18(8), 1533-1548

The original publication is available at http://link.springer.com

Doi: 10.1007/s11367-013-0588-y

Fig. 7 A revised framework for applying LCA in land planning issues

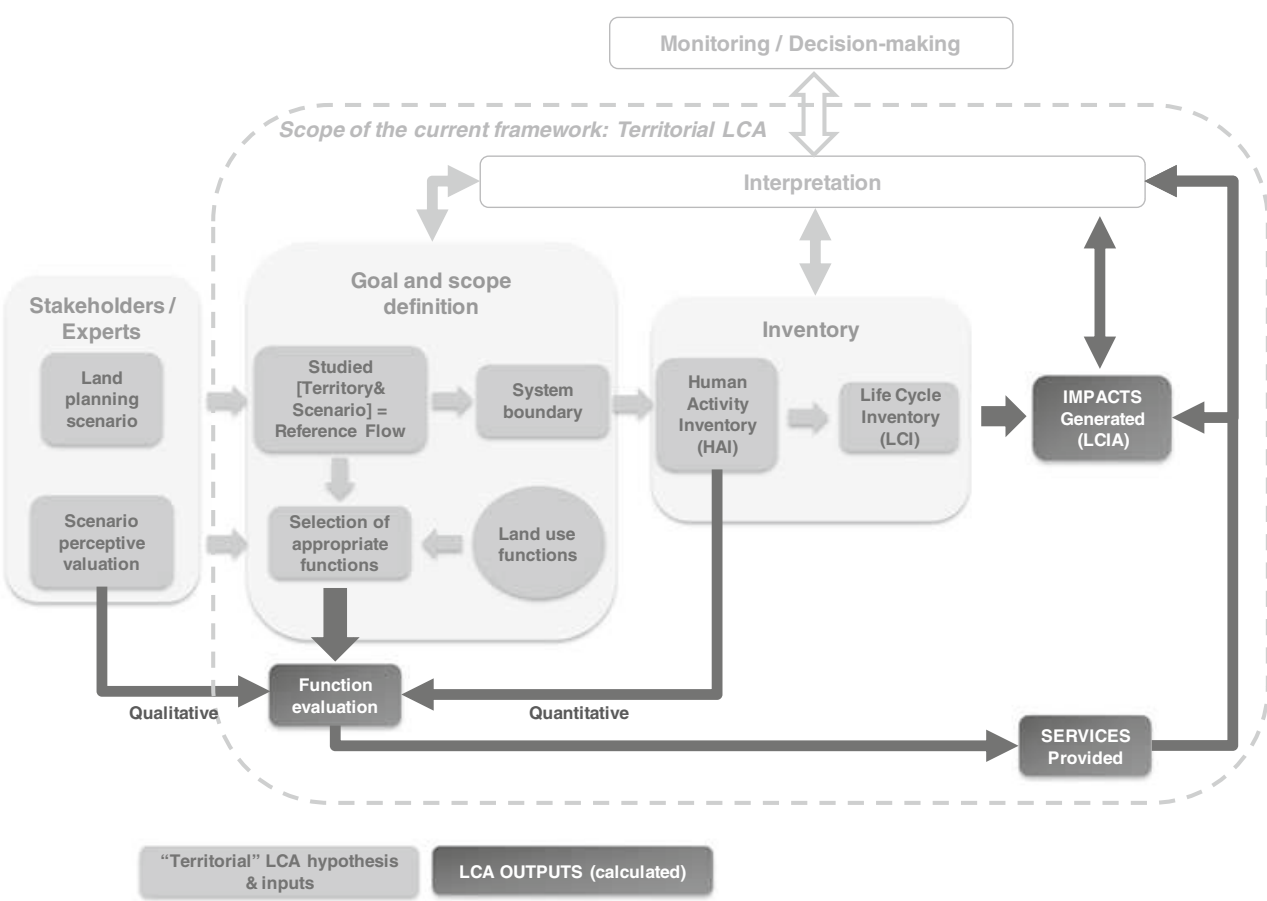

\subsubsection{Inventory, data, and sources}

To obtain accurate data on activity descriptors, bottom-up approaches are best suited. However, when such data are lacking, top-down approaches will be used. In the case study, descriptors of production activities will be defined using bottom-up approaches. A LCA based on physical processes will then be performed.

For consumption activities, a top-down approach can be used by downscaling national data on household consumption through the use of the number of inhabitants as a proxy factor. However, to improve the robustness of this approach,
Fig. 8 Schematic

representation of the theoretical case study

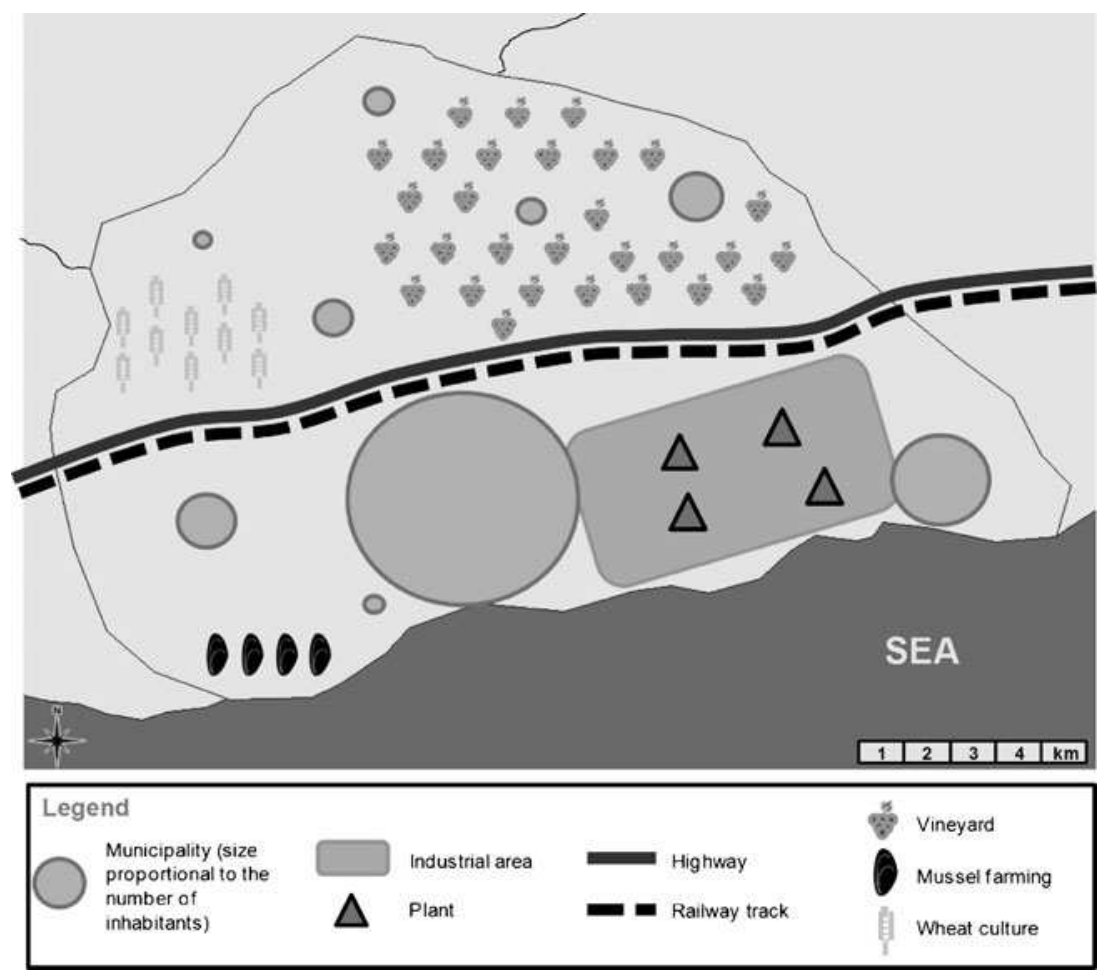


several proxy factors such as the number of workers, the purchasing power of inhabitants (Niza et al. 2009), gross domestic product, waste generation (BBF 2002), or the family's average income (Bagliani et al. 2008) can be used concurrently in order to compare results.

Combining consumption activity descriptors to life cycle inventory is complex as it covers a wide range of production activity sectors (i.e., food, durable goods, non-durable goods, services, and so on). Moreover, the study of such complex products is made more difficult due to the absence of data. Tukker and Jansen (2006) compared two different approaches to study the life cycle impacts of total societal consumption in a European context. The first one consists in bridging LCA data gaps with the use of proxy data sets (e.g., the LCA of carrots will be used to assess the impacts of the consumption of all vegetables). It is seen as a bottom-up approach. On the other hand, top-down modeling may be carried out using EIOTs. Tukker and Jansen (2006) recommended the use of top-down approaches as they are more comprehensive, consistent, and systematic in allocating environmental impacts to final consumption, whereas bottom-up studies are liable to exclude certain consumption activities due to data gaps. However, progress has been made recently concerning LCA data gaps, and several approaches have been proposed to address this issue (Milà $\mathrm{i}$ Canals et al. 2011), including for a wide range of imported and exported products (European Commission 2012b).

These two approaches have been applied concurrently to develop Canadian normalization factors based on consumption activities instead of the production-based normalization factors currently used for LCA studies (Lautier 2010). The results are quite heterogeneous and a hybrid approach is therefore recommended. Lautier (2010) applied a bottomup approach for housing and transport activities, and a topdown approach for food, goods, and services (using the US Input Output database).

We chose to adopt this portioning approach for consumption activities. This enables the use of site-specific data in housing and transport. Besides, it is not necessary to tweak the EIOTs to include the use stage. For the same reasons, the end-of-life stage has been also assessed through a bottom-up approach. This hybrid approach, which is similar to the tiered hybrid analysis, is quite easy to implement. Yet, it is important to keep in mind that this hybrid approach has some drawbacks. There is no consistency between data sources as data from the bottom-up approach come from European processes, whereas data from the top-down approach come from the USA. The use of US data is convenient for the theoretical case study. Yet, in practice, data should come from the studied area or a similar one. The data geographical origin is not the only methodological inconsistency between these two data sources. Process and EIO data may differ in terms of their level of resolution, their base year, the inclusion of capital goods, the treatment of imports, and the applied principles of allocation (Udo de Haes et al. 2004). Moreover, the combination of process and EIO data through a tiered hybrid analysis can lead to double-counting issues as stressed by Suh et al. 2004.

All data on this case study as well as key elements for their inventory are summarized in the Electronic supplementary material 4 (see S.4).

The last step of data collection, i.e., the distinction between direct burdens and indirect burdens, is simplified with the use of Ecoinvent database as it supplies two kind of processes, i.e., unit processes and system processes (Goedkoop et al. 2010). Unlike with system processes, which cover only elementary flows, unit processes contain resource and emission inputs from the process step under study as well as references to input from other unit processes. Consequently, unit processes have been used to distinguish direct burdens (all resource and emission inputs in the territory from the activity under study) from indirect burdens (all the inputs from other unit processes and outside the territory). Concerning data from input-output tables, it has been assumed that all food, goods, and services were imported and that their impacts will therefore be only indirect.

\section{Results and discussion}

\subsection{Land use functions}

Five indicators of services provided by the territory have been considered for this case study: (1) the number of employees, related to the function "provision of work", (2) the total area covered by the territory to host its population related to the function "residential, transport, and land independent production" as well as (3) the gross domestic production (GDP), (4) the number of tourists related to the function "human health, recreation and culture", and (5) the share of dwellings connected to sewage which covers the function provision of abiotic resources. For the first four indicators, data have been gathered from the activity descriptors as well as from National statistics $^{3}$ for the South of France. The indicator on area has been directly quantified thanks to the activity descriptor. To get an order of magnitude, the results have been compared to "an average territory" which is built by the downscaling of French average data ${ }^{4}$ to a theoretical territory that hosts the same population as for the case study (Fig. 9).

The results show that the case study has a high residential function as it is a densely populated territory. The other indicators are quite well balanced, except for the number

\footnotetext{
$\overline{3^{3} \mathrm{http}: / / w w w . i n s e e . f r / f r /}$

${ }^{4}$ See data on http://www.insee.fr/fr/ for the number of employees, the number of inhabitants, the GDP, and the number of tourists, and www.statistiques.developpement-durable.gouv.fr for the share of dwellings connected to sewage.
} 


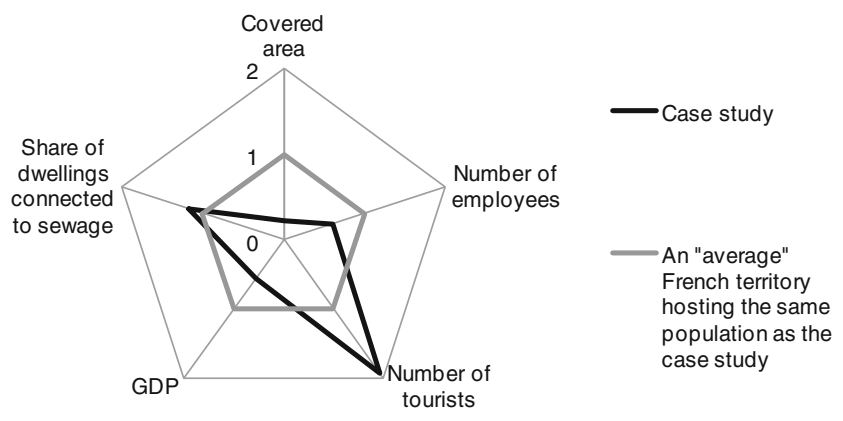

Fig. 9 Indicators of services provided by the case study compared to an "average French territory" hosting the same population

of tourists, which is high. It points out the touristic vocation of this territory.

\subsection{Environmental impacts}

The method chosen to assess the potential impacts is ReCiPe described in Goedkoop et al. (2009). The impacts are quantified at an endpoint level from the hierarchist perspective (Fig. 10).
As a general rule, the impacts from production activities are greater than those related to consumption activities. This is essentially due to impacts incurred by industrial activities. However, there are exceptions for impacts linked to land use and to freshwater ecotoxicity, which are mainly caused by consumption activities. The impacts due to the production of imported foodstuffs can partly explain these results. Besides, it should be noted that the impacts due to consumption activities are underestimated for metal depletion, ionizing radiation, and natural land transformation as they are not taken into account in the US databases of the input-output approach.

Consequently, although the indicators of land use functions suggest that residential and recreational functions prevail, environmental impacts are mainly related to production activities. This finding highlights the needs to provide two categories of outputs for the interpretation phase, i.e., land use functions and environmental impacts, as well as the importance of assessing a set of land use functions in order to grasp its multifunctionality.

A secondary yet significant result is the prevalence of indirect impacts. This means that most impacts due to

Fig. 10 Impacts generated by the theoretical case studydistinction between global and regional/local impacts as well as between direct and indirect impacts. $C$ consumption activities, $P$ production activities, $H H$ human health, $E Q$ ecosystem quality

Global Impacts

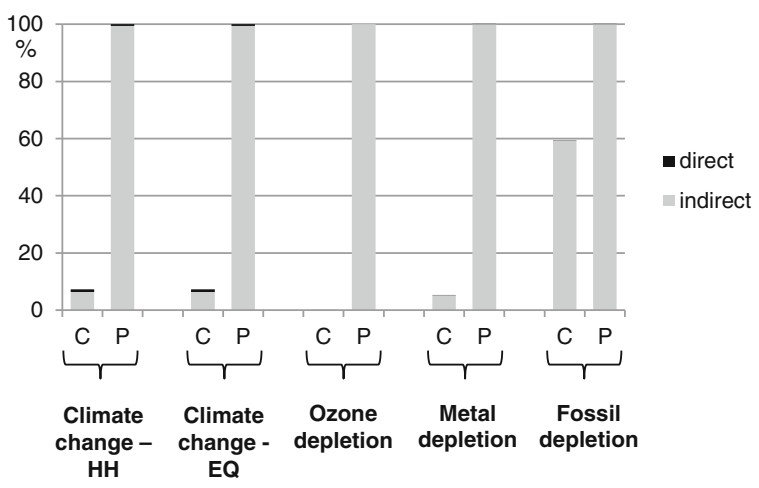

Regional / Local Impacts

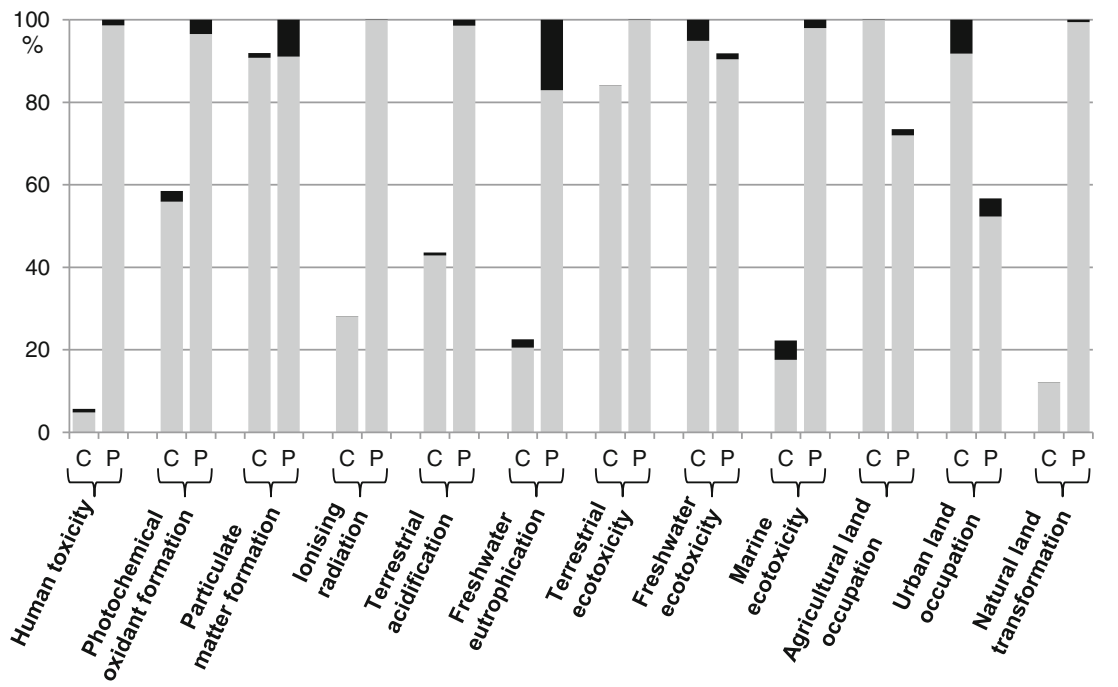


territorial activities occur elsewhere. Only a small fraction is due to local resource consumption or local releases of pollutant substances. However, these findings should not be misinterpreted. Indeed, at first sight, it is tempting to conclude that little can be done at a local level to decrease the environmental impacts with land planning. At least two arguments can be put forward to counter this hasty interpretation. Firstly, land use plans can both contribute to reduce direct and indirect environmental impacts according to the land use functions they provide. This reduction will be assessed thanks to the territorial LCA framework with the advantage of not hiding environmental burden shifting between territories. Secondly, regional and local direct impacts should be analyzed more in detail. In the case study, only site-generic characterization factors have been used with the ReCiPe method. To perform a more accurate assessment, it would be worthwhile to use site-dependent factors when they will be available in upcoming LCIA methods (such as Impact World + ) at least for the prevailing local impacts. According to the local sensitivity of the environment, regional or local actual impacts can differ from several orders of magnitude (Reap et al. 2008). Consequently, regional or local direct impacts can be important issues in a local context. It is thus recommended to identify the main contributors to these impacts in order to complete their assessment. Two steps are proposed to identify these contributors. The first is to identify the most important direct regional/local impacts. It is done by assessing their respective contribution to each of the three endpoints, i.e., human health, ecosystem quality, and resources (see the example for ecosystem quality in Fig. 11).

Concerning ecosystem quality, the main regional/local direct impacts are linked to land use and to a lesser extent to freshwater eutrophication (see Fig. 11). As a result, this assessment is useful to identify the main environmental issues at stake on the territory. The

\section{Ecosystem quality}
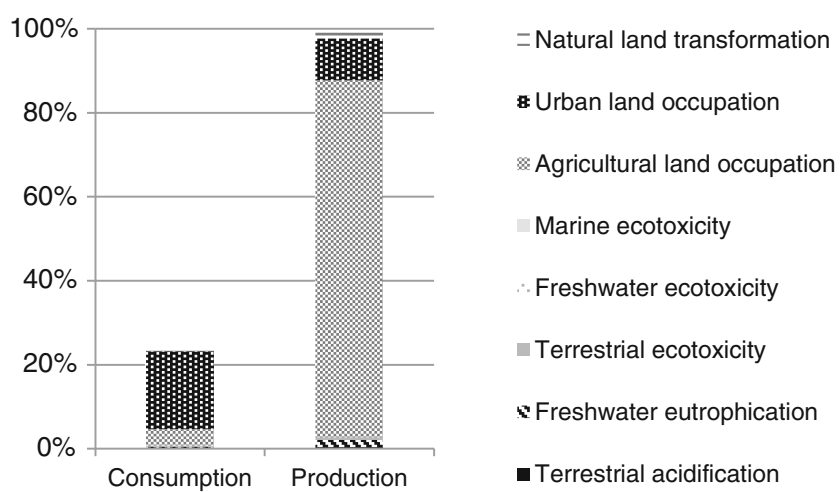

Fig. 11 Contributions of regional/local direct impacts to ecosystem quality (endpoint impact) second step is to determine what human activities generate these impacts (Fig. 12).

For instance, two main activities are responsible for agricultural land occupation, i.e., agriculture but also tourism with the establishment of numerous campgrounds on the territory. Concerning pollution-oriented impacts, direct freshwater eutrophication can be linked to both consumption activities (inhabitant-wastewater treatment) and production activities (industry). The minimal contribution of agriculture can be explained by the fact that the main production is vine growing which uses low levels of fertilizers. Once these activities have been identified, site-specific data can be used to take into account the local environment specificities in the characterization of their impacts. It will permit to assess more accurately the potential environmental risks incurred by territorial activities and to determine what the main contributors are. This will support decision-making in a local context by identifying the main drivers that could be used to reduce the environmental risks that can occur on a territory.

\section{Discussion}

\subsection{Integration in the decision-making process}

A methodological framework has been developed in order to perform territorial assessments. With the implementation of the European directive on Strategic Environmental Assessment, there is an urgent need for formalized tools which can provide quantitative indicators when assessing a territory and selecting land use planning scenarios. The SEA procedure can be divided into seven steps, i.e., (1) the scoping, (2) the situation assessment (a baseline study), (3) the formulation of alternatives, (4) the environmental analysis of these alternatives, (5) the valuation, (6) the decision, and (7) the management plan (including monitoring) (Nilsson et al. 2005). Based on these stages, territorial assessments can be performed for the situation assessment as well as for the environmental analysis of these alternatives. Territorial LCA can provide a comprehensive diagnosis of the territory, based on a global assessment of all human activities located on the territory. Besides, it will determine the main environmental issues on the territory while identifying burden shifting between environmental impacts and other territories. The use of territorial LCAs in order to compare scenarios is also supported by the assessment of the land use functions. This set of indicators allows comparing scenarios which by definition will provide different land use functions.

Consequently, territorial LCAs should be used early in the decision-making process in order to provide transparent 
Fig. 12 Contributions of human activities to direct agricultural land occupation and freshwater eutrophication. $W W T$ wastewater treatment, $W T$ waste treatment

\section{a - Consumption - Agricultural land} occupation

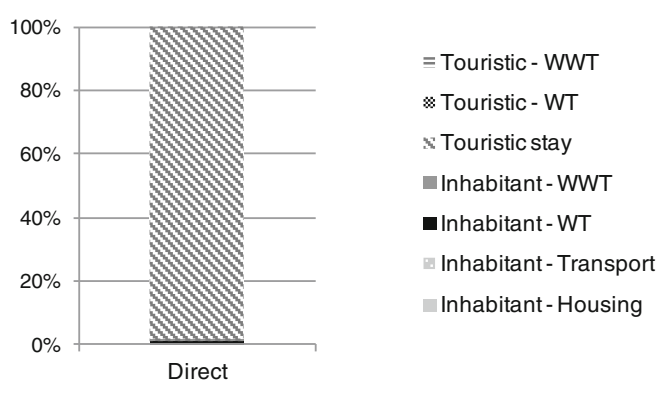

c - Consumption - Freshwater eutrophication

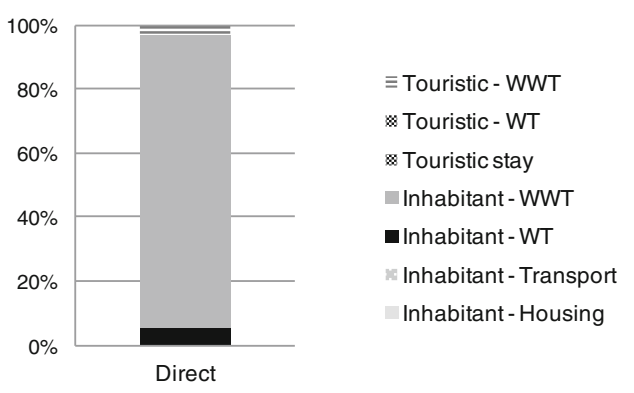

b - Production - Agricultural land occupation

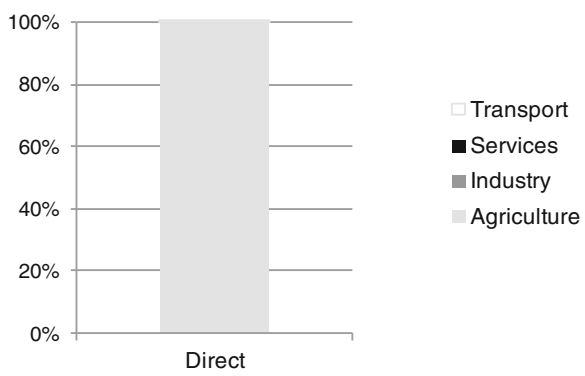

d- Production - Freshwater eutrophication

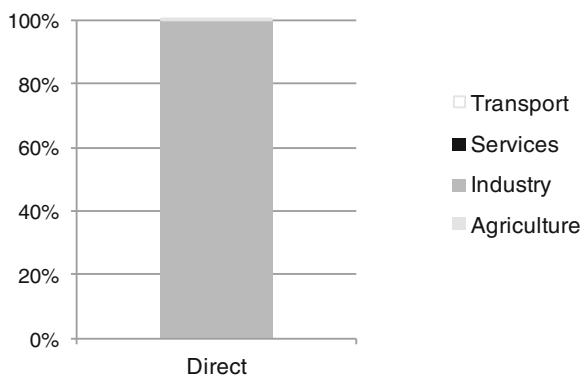

information to the stakeholders and to support a broader acceptance of SEA.

\subsection{Attributional or consequential LCA}

The aim of a "territorial LCA" is to provide relevant information for decision-making process. In order to determine whether an attributional or a consequential LCA should be performed, the recommendations of the ILCD Handbook (European Commission 2010) have been followed by studying the "extent of changes" due to the decision. As the methodological framework is dedicated to a sub-national territory level, i.e., a community of municipalities, the land use planning scenario is expected to have large consequences on the territory itself, but only small-scale and non-structural consequences on other territories. The studied territory is not big enough to put pressure on other territories via market mechanisms. Therefore, the decision support tool is for "microlevel" as defined by the ILCD handbook and an attributional modeling is thus recommended. Nevertheless, further work could be undertaken to assess under which conditions such an assumption is relevant and to explore consequential scenarios at larger scales (effect at neighboring, nation, and regional scales). For example, if the territory supports a strategic activity such as the provision of a significant part of the national energy mix, a consequential approach could be considered. The identification of these activities as well as their assessment through a consequential modeling can be performed in an additional step.

\subsection{Dealing with multifunctionality}

The proposed framework is based on the joint assessment of impacts and land use functions, which can vary depending on land use planning scenarios. As a result, the functions between scenarios are not kept equal. The approach adopted in the methodological framework is to assess a set of land use functions for each land use planning scenarios. An alternative way of dealing with the issue of multifunctionality would be to compensate for the differences of land use functions between a reference land use planning scenario and the alternatives. This other approach has the advantage of maintaining the criterion of comparability between the studied alternatives and allows comparisons. However, this would require additional work for data collecting and for compensation scenario assessment. Moreover, this could increase data uncertainty as several data would need to be approximated. Consequently, assessing compensation scenarios linked with provided function shifts can be considered rather as an extra step of territorial LCAs that could be performed once function changes have been identified between land planning scenarios.

\subsection{Addressing uncertainties}

The issue of uncertainty is common to all kinds of LCA studies. Yet, it is particularly relevant in land planning studies as we must examine prospective scenarios where additional sources of uncertainties can be multiple (data quality, modeling choices, and so on), and this signifies 
even further research (Hojer et al. 2008). One of the main issues is to connect a quantitative LCA with a prospective scenario which often rely on qualitative descriptions combined with a GIS-based land use planning. The qualitative descriptors must be turned into quantitative functions. One possible approach is to make assumptions on the levels of human activities from a prospective scenario (e.g., the number of inhabitants, the number of tourists, etc.). This can be discussed with the stakeholders in charge of defining the different land use planning scenarios. Thereafter, a sensitivity analysis could be conducted in order to estimate the consequences of these assumptions on the results.

\subsection{Links with GIS (Geographic Information System) tools}

The use of GIS (Geographic Information System) tools can prove very useful in environmental assessment in land planning, as stressed by Azapagic et al. (2007). They can provide two main improvements. The first one is to enhance the inventory phase by developing a "spatialized" inventory. For each activity, it will associate inventory data to spatial data on their location. The second would be to use spatial analysis tools to provide valuable information for sitespecific assessment. It would be particularly relevant if an environmental risk assessment needs to be performed for activities identified in the screening step.

\section{Conclusions}

Methodological advances have been proposed to adapt the LCA framework to land planning issues. One of the main transformations of this "territorial LCA" framework is that the functional unit would no longer be "the geographical territory", but a set of indicators, i.e., a vector grouping a set of land use functions which is the counterpart of the vector of potential environmental impacts, which is the output of conventional LCA. This adapted framework intends to pave the way for providing quantitative tools to land planning managers when assessing the environmental effects of plans or programs. The aim of this paper was not to meet all the SEAs needs but to contribute to improve it by (1) providing an environmental baseline of a territory and (2) comparing quantitatively different land planning alternatives.

A first attempt has been made to determine and classify goods and services according to land use functions (see Table 1). This approach requires further work, i.e., should we retain all the goods and services of this list, or only some of them, based on stakeholder interest? Should we add other goods and services which are relevant for stakeholders? The values to be assigned to each variable should be determined in the scenario building phase. This evaluation is crucial for the task of measuring the eco-efficiency of a territory as developed by Seppälä et al. (2005).

Although the path is still long until a fully integrated methodology becomes operational, this revised approach provides food for thought on how to best integrate the two categories of indicators. In terms of usability, it will be beneficial for decision makers to get all these indicators on a same dashboard (e.g., environmental but also economic and social indicators). This is in line with ongoing research work on life cycle sustainability assessment (Guinée et al. 2011) and the challenges related to the extension of the environmental life cycle thinking to economic and social aspects (Hunkeler and Rebitzer 2005).

Acknowledgments This research has been supported by Irstea, AgroParisTech, the Languedoc Roussillon Regional Council, and the Ecotech-Sudoe project funded by the Interreg IV program and the FEDER. The authors thank Cécile Bulle for her assistance and her advice as well as Nathalie Chèvre and Alain Grasmick. The authors are members of the ELSA research group (Environmental Life Cycle and Sustainability Assessment, http://www.elsa-lca.org/); they thank all the other members of ELSA for their advice.

\section{References}

Azapagic A, Pettit C, Sinclair P (2007) A life cycle methodology for mapping the flows of pollutants in the urban environment. Clean Technol Environ Policy 9:199-214

Bagliani M, Galli A, Niccolucci V, Marchettini N (2008) Ecological footprint analysis applied to a sub-national area: the case of the Province of Siena (Italy). J Environ Manage 86:354-364

Banski J, Bednarek M, Danes M et al (2011) EU-LUPA: European Land Use Patterns. EPSON 2013 Programme, Luxembourg

Bare JC, Norris GA, Pennington DW, McKone TE (2003) TRACI, the tool for the reduction and assessment of chemical and other environmental impact. J Ind Ecol 6:49-78

Baumgartner DU, Mieleitner J, Alig M, Gaillard G (2011). Environmental profiles of farm types in Switzerland based on LCA. In: Finkbeiner M (ed) Towards life cycle sustainability management. Life Cycle Management 2011. Springer, Berlin

BFF Ltd (Best Foot Forward) (2002) City limits: a resource flow and ecological footprint analysis of Greater London

Björklund A (2012) Life cycle assessment as an analytical tool in strategic environmental assessment. Lessons learned from a case study on municipal energy planning in Sweden. Environ Impact Assess Rev 32:82-87

Browne D, O'Regan B, Moles R (2011) Material flow accounting in an Irish city-region 1992-2002. J Cleaner Prod 19:967-976

Browne D, O'Regan B, Moles R (2008) Use of embodied energy and ecological footprinting to assess the global environmental impact of consumption in an Irish city-region. J Environ Plann Man $51: 447-470$

Cao V, Margni M, Favil BD, Deschênes L (2012) Development of an integrated indicator for land use based on ecosystem services. SETAC Europe 22nd Annual Meeting/6th SETAC World Congress, Berlin

Chanard C, Sède-Marceau M-H de, Robert M (2011) Politique énergétique et facteur 4 : instruments et outils de régulation à disposition des collectivités. Développement durable et territoires 2. URL: http://developpementdurable.revues.org/8776 
Cooper JS (2003) Specifying functional units and reference flows for comparable alternatives. Int J Life Cycle Assess 8:337-349

Costanza R, d' Arge R, de Groot R et al (1997) The value of the world's ecosystem services and natural capital. Nature 387:253260

Curran MA (2006) LCA: principles and practices. USEPA National Risk Management Research Laboratory, Cincinnati

DATAR (2003) Quelle France rurale pour 2020? Contribution à une nouvelle politique de développement rural durable. Report, France

Eder P, Narodoslawsky M (1999) What environmental pressures are a region's industries responsible for? A method of analysis with descriptive indices and input-output models. Ecol Econ 29:359374

Ekvall T, Tillman A, Molander S (2005) Normative ethics and methodology for life cycle assessment. J Cleaner Prod 13:1225-1234

European Commission (2009) Report from the Commission to the Council, the European Parliament, the European Economic and Social Committee and the Committee of the Regions on the application and the effectiveness of the Directive on Strategic Environmental Assessment (Directive 2001/42/EC). Brussels

European Commission (2010) International Reference Life Cycle Data System (ILCD) Handbook-General Guide for Life Cycle Assessment-Detailed Guidance. First Edition, Publication Office of the European Union. European Commission, Joint Research Center, Institute for Environment and Sustainability

European Commission (2012a) Life cycle indicator framework: development of life cycle based macro-level monitoring indicators for resources, products and waste for the EU-27. European Commission, Joint Research Center, Institute for Environment and Sustainability

European Commission (2012b) Life cycle indicators for resources: development of life cycle based macro-level monitoring indicators for resources, products and waste for the EU-27. European Commission, Joint Research Center, Institute for Environment and Sustainability

EU (2001) Directive 2001/42/EC of the European Parliament and of the Council of 27 June 2001 on the assessment of the effects of certain plans and programmes on the environment

Eurostat (2008) NACE Rev. 2-statistical classification of economic activities in the European Community. Office for Official Publications of the European Communities, Luxembourg

Ferng J-J (2003) Allocating the responsibility of $\mathrm{CO}_{2}$ over-emissions from the perspectives of benefit principle and ecological deficit. Ecol Econ 46:121-141

Finnveden G, Hauschild MZ, Ekvall T et al (2009) Recent developments in life cycle assessment. J Environ Manage 91:1-21

Finnveden G, Nilsson M (2005) Site-dependent life-cycle impact assessment in Sweden. Int J Life Cycle Assess 10:235-239

Frischknecht R (1998) Life cycle inventory analysis for decisionmaking-scope-dependent inventory systems models and context-specific joint product allocation. Ph.D. thesis, Swiss Federal Institute of Technology, Zurich

García G, Abajo B, Olazabal M et al. (2009) A step forward in the evaluation of urban metabolism: definition of urban typologies. ConAccount 2008: Urban metabolism: measuring the ecological city, Prague

Goedkoop M, Heijungs R, Huijbregts M et al. (2009) ReCiPe 2008-a life cycle impact assessment method which comprises harmonised category indicators at the midpoint and the endpoint level. Report, The Netherlands

Goedkoop M, De Schryver A, Oele M et al. (2010) Introduction to LCA with SimaPro 7. Report, PRé Consultants, The Netherlands

Goldstein B (2012) Hybrid urban metabolism models and sustainable urban development. Master thesis project, Environmental Engineer DTU, Denmark
Gómez-Limón JA, Vera-Toscano E, Rico-González M (2012) Measuring individual preferences for rural multifunctionality: the importance of demographic and residential heterogeneity. J Agr Econ 63:1-24

Guinée JB, Heijungs R, Huppes G et al (2011) Life cycle assessment: past, present, and future. Environ Sci Technol 45:90-96

Haas G, Wetterich F, Geier U (2000) Life cycle assessment framework in agriculture on the farm level. Int J Life Cycle Assess 5:345-348

Hauschild M, Potting J (2003) Spatial differentiation in life cycle impact assessment - the EDIP2003 methodology. Report, Institute for Product development, Technical University of Denmark, Copenhagen

Helming K, Diehl K, Bach H et al. (2011a) Ex ante impact assessment of policies affecting land use, part A: analytical framework. Ecol Soc 16. URL: http://www.ecologyandsociety.org/vol16/iss1/ $\operatorname{art27/}$

Helming K, Diehl K, Kuhlman T et al. (2011b) Ex ante impact assessment of policies affecting land use, part B: application of the analytical framework. Ecol Soc 16. URL: http:// www.ecologyandsociety.org/vol16/iss1/art29/

Hojer M, Ahlroth S, Dreborg K et al (2008) Scenarios in selected tools for environmental systems analysis. J Cleaner Prod 16:1958-1970

Huijbregts M, Seppälä J (2000) Towards region-specific, European fate factors for airborne nitrogen compounds causing aquatic eutrophication. Int J Life Cycle Assess 5:65-67

Huijbregts MAJ, Schöpp W, Verkuijlen E et al (2000) Spatially explicit characterization of acidifying and eutrophying air pollution in life-cycle assessment. J Ind Ecol 4:75-92

Hunkeler D, Rebitzer G (2005) The future of life cycle assessment. Int J Life Cycle Assess 10:305-308

ISO (2006a) Environmental management-life cycle assessmentprinciples and framework. ISO 14040. International Organisation for Standardisation, Geneva

ISO (2006b) Environmental management-life cycle assessmentrequirements and guidelines. ISO 14044. International Organisation for Standardisation, Geneva

ISO (1998) Environmental management-life cycle assessment-goal and scope definition and inventory analysis. International Organisation for Standardisation, Geneva

Jean B (2009) La multifonctionnalité des territoires ruraux: une nouvelle figure de la ruralité et une nouvelle perspective de développement territorial. Chaire de recherche du Canada en développement durable. Université du Québec à Rimouski, Canada

Jolliet O, Margni M, Charles R et al (2003) IMPACT 2002+: a new life cycle impact assessment methodology. Int J Life Cycle Assess 8:324-330

Kaenzig J, Jolliet O (2006) Consommation respectueuse de l'environnement: décisions et acteurs clés, modèles de consommation. Report, Office fédéral de l'environnement (OFEV), Berne

Krewitt W, Trukenmüller A, Bachmann TM, Heck T (2001) Countryspecific damage factors for air pollutants. Int J Life Cycle Assess 6:199-210

Lautier A (2010) Mettre en contexte les résultats d'une Analyse de Cycle de Vie-Développement de facteurs de normalisation canadiens et problématique de la définition des frontières. Master's thesis, Département de Génie chimique, Ecole Polytechnique de Montréal, Canada

Lenzen M (2001) Erros in conventional and input-output-based lifecycle inventories. J Ind Ecol 4:127-148

Lenzen M (2008) Double-counting in life cycle calculations. J Ind Ecol 12:583-599

Loiseau E, Junqua G, Roux P, Bellon-Maurel V (2012) Environmental assessment of a territory: an overview of existing tools and methods. J Environ Manage 112:213-225 
Lundie S, Peters GM, Beavis PC (2004) Life cycle assessment for sustainable metropolitan water systems planning. Environ Sci Technol 38:3465-3473

Milà i Canals L, Azapagic A, Doka G et al (2011) Approaches for addressing life cycle assessment data gaps for bio-based products. $\mathrm{J}$ Ind Ecol 15:707-725

Minx JC, Creutzig F, Medinger V et al. (2011) Developing a pragmatic approach to assess urban metabolism in Europe. Report, European Environment Agency, Copenhagen

Moine A (2006) Le territoire comme un système complexe: un concept opératoire pour l'aménagement et la géographie. L'Espace géographique 35:115-132. http://www.cairn.info/revue-espacegeographique-2006-2-page-115.htm

Muradian R, O'Connor M, Martinez-Alier J (2002) Embodied pollution in trade: estimating the "environmental load displacement" of industrialised countries. Ecol Econ 41:51-67

Niza S, Rosado L, Ferrão P (2009) Urban metabolism. J Ind Ecol 13:384-405

Nilsson M, Björklund A, Finnveden G, Johansson J (2005) Testing a SEA methodology for the energy sector: a waste incineration tax proposal. Environ Impact Assess 25:1-32

Owens JW (1997) Life-cycle assessment: constraints on moving from inventory to impact assessment. J Ind Ecol 1:37-49

Paracchini ML, Pacini C, Jones MLM, Pérez-Soba M (2011) An aggregation framework to link indicators associated with multifunctional land use to the stakeholder evaluation of policy options. Ecol Indic 11:71-80

Pérez-Soba M, Petit S, Jones MLM et al. (2008) Land use functions-a multifunctionality approach to assess the impact of land use change on land use sustainability. In: Helming K, Pérez-Soba M, Tabbush P (eds) Sustainability impact assessment of land use changes. Springer, Berlin, pp. 375-404

Potting J, Hauschild M (1997) Predicted environmental impact and expected occurrence of actual environmental impact part 1: the linear nature of environmental impact form emissions in life-cycle assessment. Int J Life Cycle Assess 2:171-177

Potting J, Hauschild MZ (2005) Background for spatial differentiation in life cycle impact assessment - the EDIP 2003 methodology. Danish Environmental Protection Agency, Copenhagen

Potting J, Schöpp W, Blok K, Hauschild M (1998) Site-dependent lifecycle impact assessment of acidification. J Ind Ecol 2:63-87

Reap J, Roman F, Duncan S, Bras B (2008) A survey of unresolved problems in life cycle assessment. Part 2: impact assessment and interpretation. Int J Life Cycle Assess 13:374-388

Rebitzer G, Ekvall T, Frischknecht R et al (2004) Life cycle assessmentpart I: framework, goal and scope definition, inventory analysis and applications. Environ Int 30:701-720

Reidsma P, König H, Feng S et al (2011) Methods and tools for integrated assessment of land use policies on sustainable development in developing countries. Land Use Policy 28:604-617

Seppälä J, Melanen M, Mäenpää I et al (2005) How can the ecoefficiency of a region be measured and monitored? J Ind Ecol 9:117-130

Siqueira Lemos D (2011) Urban metabolism of Aveiro: LCA of the city demands and water cycle. Master's thesis, University of Aveiro
Spielmann M, Scholz R, Tietje O, de Haan P (2004) Scenario modelling in prospective LCA of transport systems. Application of formative scenario analysis. Int J Life Cycle Assess 10:325-335

Suh S, Lenzen M, Treloar GJ, Hondo H, Horvath N, Huppes G, Jolliet O, Klann U, Krewitt W, Moriguchi Y, Munskgaard J, Norris G (2004) System boundaries selection in life-cycle inventories using hybrid approaches. Environ Sci Technol 38:657-664

Suh S, Huppes G (2005) Methods for life cycle inventory of a product. J Cleaner Prod 13:687-697

Thabrew L, Wiek A, Ries R (2009) Environmental decision making in multi-stakeholder contexts: applicability of life cycle thinking in development planning and implementation. J Cleaner Prod 17:67-76

Tillman A (2000) Significance of decision-making for LCA methodology. Environ Impact Assess 20:113-123

Toffoletto L, Bulle C, Godin J et al (2006) LUCAS - a new LCIA method used for a Canadian-specific context. Int J Life Cycle Assess 12:93-102

Toffoletto L, Deschênes L, Samson R (2004) LCA of ex-situ bioremediation of diesel-contaminated soil. Int $\mathrm{J}$ Life Cycle Assess 10:406-416

Tukker A, Jansen B (2006) Environmental impacts of products: a detailed review of studies. J Ind Ecol 10:159-182

Udo de Haes H, Bensahel JF, Clift R et al. (1994) Guidelines for the application of life-cycle assessment in the EU Ecolabelling Programme. Report, Leiden, The Netherlands

Udo de Haes HA (1996) Towards a methodology for life cycle impact assessment. SETAC_-Europe, Brussels

Udo de Haes HA, Finnveden G, Goedkoop M et al (2002) Life-cycle impact assessment: striving towards best practice. SETAC, Pensacola

Udo de Haes HA, Heijungs R, Suh S, Huppes G (2004) Three strategies to overcome the limitations of life-cycle assessment. J Ind Ecol 8:19-32

United Nations (1992) Action 21-The United Nations Programme of Action from Rio. The United Nations Conference on Environment and Development, Rio de Janeiro

Weidema BP, Nielsen AM, Christiansen K et al (2005) Prioritisation within the Integrated Product Policy. Environmental project Nr. 980 2005. The Danish Environmental Protection Agency, Copenhagen

Wiedmann T, Lenzen M, Turner K, Barrett J (2007) Examining the global environmental impact of regional consumption activitiespart 2: review of input-output models for the assessment of environmental impacts embodied in trade. Ecol Econ 61:15-26

Wiggering H, Müller K, Werner A, Helming K (2003) The concept of multifunctionality in sustainable land development. In: Helming $\mathrm{K}$, Wiggering $\mathrm{H}$ (eds) Sustainable development of multifunctional landscapes. Springer, Berlin, pp 3-18

Wilting HC, Ros JPM (2006) Comparing the environmental effects of production and consumption in a region: a tool for policy. In: Suh $\mathrm{S}$ (ed) Handbook of input-output economics in industrial ecology. Springer, Berlin, pp. 379-396

Yi I, Itsubo N, Inaba A, Matsumoto K (2007) Development of the interregional I/O based LCA method considering region-specifics of indirect effects in regional evaluation. Int J Life Cycle Assess $12: 353-364$ 